Sciences

Vol. 06, No. 04, pp. 15-37, December 2013

\title{
FINITE ELEMENT ANALYSIS OF REINFORCED CONCRETE SLABS WITH SPHERICAL VOIDS
}

\author{
Amer M. Ibrahim ${ }^{1}$, Nazar K. Ali ${ }^{2}$ and Wissam D. Salman ${ }^{3}$ \\ ${ }^{1}$ prof., College of Engineering, Diyala University, Iraq. \\ ${ }^{2}$ Asst. prof., College of Engineering, Baghdad University, Iraq. \\ ${ }^{3} \mathrm{PhD}$ Student, College of Engineering, Baghdad University, Iraq. \\ (Received: 30/4/2012; Accepted: 7/6/2012)
}

\begin{abstract}
This paper presents a numerical analysis using ANSYS finite element program to simulate the reinforced concrete slabs with spherical voids when subjected to five point load. Six slabs with length $1.0 \mathrm{~m}$, width $1.0 \mathrm{~m}$, height $(0.1 \mathrm{~m}$ and $0.125 \mathrm{~m})$ and simply supported were modeled. Nonlinear materials behavior, as it relates to steel reinforcing bars and plain concrete, and linear behavior for steel plate is simulated using appropriate constitutive models. The results showed that the general behavior of the finite element models represented by the load-deflection curves at mid-span, ultimate load, load-maximum concrete compressive strain curve, and crack patterns show good agreement with the test data from the experimental test. The finite element models represented by this work can be used to carry out parametric study for the BubbleDeck slab specimens.
\end{abstract}

Keywords: Finite Element Modeling; Reinforced Concrete Slab; BubbleDeck slab.

\section{1- INTRODUCTION}

In buildings, the slab is a very important structural member. And the slab is one of the largest members consuming concrete ${ }^{(1)}$. In a general way, the slab was designed only to resist vertical load. However, as people are getting more interest of residential environment recently, noise and vibration of slab are getting more important ${ }^{(2)}$. In addition, when the span of the building is increasing, deflection of slab is more important. Therefore, the slab thickness is on the increase. Increasing slab thickness makes slabs heavier, and it leads to increased column and base size. Thus, it makes buildings consume more materials such as concrete and steel ${ }^{(3)}$. 
To avoid these disadvantages which were caused by increasing self-weight of slabs, the BubbleDeck slab system, also known as void slab, was suggested. This system consists of hollow plastic spheres cast into the concrete to create a grid of void forms inside the slab and have a major contribution to the objective of sustainable buildings ${ }^{(4)}$. This slab system could optimize the size of vertical members like walls and columns by lightening the weight of slabs ${ }^{(5)}$.

In this paper, A theoretical analysis to predict the flexural (ultimate load, deflection, concrete compressive strain and crack pattern) of both solid and BubbleDeck specimens were performed, using a nonlinear finite element (ANSYS 12) program $^{(6)}$ based on the three third scale reinforced concrete slab tested through the $\mathrm{PhD}$ research.

\section{2-DETAILS OF EXPERIMENTAL TEST}

\subsection{Outline of Program}

Six slabs were tested, full details of their dimensions, arrangement of reinforcing steel and loading set up are shown in Figure (1) and variables studied are given in Table (1).

\subsection{Material Properties}

For the slab specimens, the design compressive strength of $33 \mathrm{MPa}$ was used. The concrete mixture proportions are presented in Table (2). For each series of casting, the specified compressive strength is measured by testing three concrete cylinders. Different sizes of reinforcing bars, 4 and $5 \mathrm{~mm}$ were used in specimens. For each bar size, three samples were tested under tension. The yield and ultimate strength of different bars are given in Table (3).

The plastic spheres used in this project are manufactured in Iraq (at AL-SABAH factory), from recycled plastic with different diameters of $(64 \mathrm{~mm}$ and $80 \mathrm{~mm})$. The purpose of using recycled material is to curb consumption of finite natural resources such as oil and minimize the burden on the environment through the cyclical use of resources, therefore the recycling martial reduces inputs of new resources and limits the burden on the environment and reduces the risks to human health.

\subsection{Tested Method and Measurement}

Specimens were tested under a five-point load system using a five hydraulic jack and a five loading plate to satisfy the actual loading condition. For all slab specimens, the first 
crack load, deflection at mid-span, maximum concrete compressive strain and ultimate load were measured.

\section{3- MATERIAL PROPERTIES AND CONSTITUTIVE MODELS}

\section{Element Type}

An eight-node solid element, Solid65, was used to model the concrete. The solid element has eight nodes with three degrees of freedom at each node-translations in the nodal $\mathrm{x}, \mathrm{y}$ and $\mathrm{z}$ directions. The element is capable of plastic deformation, cracking in three orthogonal directions, and crushing. The geometry and node locations for the element type are shown in Figure (2).

A Link 8 was used to model the steel reinforcement. Two nodes are required for this element. Each node has three degrees of freedom, at each node-translations in three nodal x, y and $\mathrm{z}$ directions. The element is also capable of plastic deformation. The geometry and node locations for this element type are shown in Figure (3).

An eight-node solid element, Solid45, was used for the steel plates at the supports and applied load location in the slab models. The element is defined with eight nodes having three degrees of freedom at each node-translations in the nodal $x, y$ and $z$ directions. The geometry and node locations for the element type are shown in Figure (4).

\subsection{MODELING OF MATERIAL PROPERTIES}

\subsubsection{Concrete}

In compression, the stress-strain curve for concrete is linearly elastic up to about 30 percent of the maximum compressive strength. Above this point, the stress increases gradually up to the maximum compressive strength. After it reaches the maximum compressive strength ${ }^{\sigma}$, the curve descends into a softening region, and eventually crushing failure occurs at an ultimate $\operatorname{strain}{ }_{c u}$. In tension, the stress-strain curve for concrete is approximately linearly elastic up to the maximum tensile strength. After this point, the concrete cracks and the strength decreases gradually to zero. Figure (5) shows typical uniaxial compressive and tensile stress-strain curve for concrete. The present study assumed that the concrete is a homogeneous and initially isotropic. The compressive uniaxial stressstrain relationship for the concrete model is obtained by using the following equations which 
can be used to compute the multilinear isotropic stress-strain curve for the concrete ${ }^{(7),(8)}$ is as shown in Figure (6) ${ }^{(9)}$.

$f_{C}=\varepsilon E_{c}$ for $0 \leq \varepsilon \leq \varepsilon_{1}$

$f_{c}=\frac{\varepsilon E_{c}}{1+\left[\frac{\varepsilon}{\varepsilon_{0}}\right]^{2}}$ for $\varepsilon_{1} \leq \varepsilon \leq \varepsilon_{0}$

$f_{c}=f_{c}^{\prime} \quad$ for $\varepsilon_{0} \leq \varepsilon \leq \varepsilon_{c u}$

$\varepsilon_{0}=\frac{2 f_{c}^{\prime}}{E_{c}} \quad$ for $\varepsilon_{0} \leq \varepsilon \leq \varepsilon_{c u}$

The simplified stress-strain curve for each beam model is constructed from six points connected by straight lines. The curve starts at zero stress and strain. Point 1 , at $0.3 \mathrm{f}_{\mathrm{c}}^{\prime}$, is calculated for stress-strain relationship of the concrete in the linear range (must satisfy Hooke's law). Point 5 is at $\varepsilon_{0}$ and $\mathrm{f}_{\mathrm{c}}^{\prime}$. The behavior is assumed to be perfectly plastic after point $5^{(10) \text {. }}$

\subsubsection{Steel}

Steel was assumed to be an elastic-perfectly plastic material and identical in tension and compression. Poisson's ratio of 0.3 was used for steel reinforcement in this study, Figure (7) shows the stress-strain relationship used in this study. Material properties for the steel reinforcement for all models are as follows:

Elastic modulus, Es $=200,000 \mathrm{MPa}$, Poisson's ratio $\gamma=0.3$

\section{4- ANALYTICAL METHODOLOGY}

Graphical User Interface (GUI) method with ANSYS.

$\Rightarrow$ Modeling, Meshing, Solution control, Loading, Solution, General post-processing, Time history post-processing.

All element types of working model are shown in Table (4), material properties for calibration model are shown in Table (5). Figures (8), (9), (10), (11) and (12) show the volumes created in ANSYS, meshing, reinforcing modeling, symmetry of one quarter, and boundary condition of external load, respectively.

\section{5- NUMERICAL ANALYSIS AND COMPARISION OF RESULTS}

\subsection{Load-Deflection curves}


Deflections are measured at mid-span at the center of the bottom face of the slab. Figures (13) to (18) show the load-deflection curves for the control and BubbleDeck slabs for experimental and analytical results. In general, the load deflection curves for the slabs from the finite element analyses agree quite well with the experimental data. The finite element load deflection curves in the linear range are somewhat stiffer than the experimental plots. After first cracking, the stiffness of the finite element models is again higher than that of the experimental slabs. There are several effects that may cause the higher stiffness in the finite element models. First, micro-cracks are present in the concrete for the experimental slabs, and could be produced by drying shrinkage in the concrete and/or handling of the slabs. On the other hand, the finite element models do not include the micro-cracks. The micro-cracks reduce the stiffness of the experimental slabs. Next, perfect bond between the concrete and steel reinforcing is assumed in the finite element analyses, but the assumption would not be true for the experimental slabs. As bond slip occurs, the composite action between the concrete and steel reinforcing is lost. Thus, the overall stiffness of the experimental slab is expected to be lower than for the finite element model (which also generally imposed additional constraints on behavior).

The deflected shapes due to applied loads are shown in Figures (16) to (24).

\subsection{Loads at Failure}

Table (6) shows comparison between the ultimate load of the experimental slabs and the final load from the finite element model. The final load for the finite element model at the last applied load step before the solution diverges due to numerous cracks and large deflections. It is seen that the ANSYS models underestimate the strengths of the slabs, as anticipated. One explanation is that the toughening mechanisms at the crack faces, i.e. the grain bridging process, interlocking between the cracked faces, crack tips blunted by voids, and the crack branching process, may also slightly extend the failures of the experimental slabs before complete collapse. The finite element models do not have these mechanisms. Finally, the material properties assumed in this study may be imperfect.

\subsection{Load-Strain Curves}

Figures (25) to (30) show the load versus extreme compression fiber strain response of the concrete slabs observed from experimental and analytical study (computer program) for solid and BubbleDeck slabs. It is shown that the analytical compressive strains and corresponding experimental strains are very close throughout the entire loading. 


\subsection{Crack pattern}

The ANSYS program records a crack pattern at each applied load step. Figures (31) to (36) show comparison of crack patterns between experimental and finite element at load failure. The failure modes of the finite element models show good agreement with observations and data from the experimental slabs. In general, flexural cracks occur early at mid-span. When applied loads increase, vertical flexural cracks spread horizontally from the mid-span to the support. At a higher applied load, diagonal tensile cracks appear. Increasing applied loads induces additional diagonal and flexural cracks. Finally, compressive cracks appear at nearly the last applied load steps. ANSYS program displays circles at locations of cracking or crushing in concrete elements. Cracking is shown with a circle outline in the plane of the crack, and crushing is shown with an octahedron outline. The first crack at an integration point is shown with a red circle outline, the second crack with a green outline, and the third crack with a blue outline ${ }^{(6)}$.

\section{6- CONCLUSION}

In this paper, nonlinear finite element analyses of reinforced concrete slabs with plastic spheres are performed. Based on the numerical results, the following conclusions may be drawn:

1. The general behavior of the finite element models represented by the load-deflection curves at mid-span show good agreement with the test data from the slabs tests. However, the finite element models show slightly more stiffness than the test data in both the linear and nonlinear ranges. The effects of bond slip (between the concrete and steel reinforcing) and microcracks occurring in the actual slabs were excluded in the finite element models, contributing to the higher stiffness of the finite element models.

2. The load-deflection curves for selected locations from the finite element analysis show fair agreement with the test data.

3. The final loads from the finite element analyses are lower than the ultimate loads from the experimental results. This is probably due to ignoring the effects of concrete toughening mechanisms.

4. The load carrying capacity of the BubbleDeck slab predicted by the finite element analysis is lesser than that of the control slab (solid slab).

5. The crack patterns at the final loads from the finite element models correspond well with the observed failure modes of the experimental slabs. 


\section{7- REFERENCES}

1- J.H. Chung, B.H. Kim, H.K. Choi, S.C Lee and C.S. Choi: "Flexural capacities of hollow slab with material properties”. Proceedings of the Korea Concrete Institute. Vol.22 No.1 (2010).

2- J.H. Chung, N.K. Ahn, H.K. Choi. and C.S. Choi:" An analytical study of optimal hollow sphere shapes in hollow slab". Journal of the Korea institute for structural maintenance. (2009).

3- J.H. Chung, H.K. CHOI, S.C. LEE, J.K. Oh. and C.S. Choi: “An Analytical Study of the Impact of Hollow Sphere on Biaxial Hollow slab". Proceeding of annual conference of the architectural institute of Korea. (2009).

4- Ing. A.C. Fuchs Deputy Director. "BubbleDeck Floor System - An Iinnovative Sustainable Floor System" BubbleDeck Netherlands B.V., AD Leiden, the Netherlands, (2009).

5- Schellenbach -Held, Stefan Ehmann, Karsten Pfeffer. "BubbleDeck - New Ways in Concrete Building”. Technical University Darmstadt's, Germany, (1998).

6- ANSYS, "ANSYS Help", Release 12.0, Copyright (2009).

7- Desayi, P. and Krishnan, S., "Equation for the Stress-Strain Curve of Concrete", Journal of the American Concrete Institute, 61, pp. 345-350, March (1964).

8- Gere, J. M. and Timoshenko, S. P., "Mechanics of Materials", PWS Publishing Company, Boston, Massachusetts (1997).

9- Wolanski A. J., "Flexural Behavior of Reinforced and Prestressed Concrete Beams using Finite Element Analysis”, M.Sc. Thesis, University of Marquette, May (2004).

10- Kachlakev, D. I. and Mccurry D.I., "Simulated Full Scale Testing of Renforced Concrete Beams Strengthened with FRP Composite: Experimental Results and Design Model Verification" United State Department of Transportation, Fedral Highway Administration (2000).

11- Chen W. F., "Plasticity in Reinforced Concrete", McGraw-Hill Book Company, (1982).

12- Desayi P., and Krishnan, S., "Equation for the Stress-Strain Curve of Concrete", Journal of the American Concrete Institute, Vol. 61, March (1964), pp. 345- 350. 
Table (1): Properties of Tested Slab Specimens.

\begin{tabular}{|c|c|c|c|c|c|c|c|c|c|c|}
\hline No. & $\begin{array}{c}\text { Specimen } \\
\text { name }\end{array}$ & $\begin{array}{c}\text { Length } \\
(\mathrm{mm})\end{array}$ & $\begin{array}{l}\text { Width } \\
(\mathrm{mm})\end{array}$ & $\begin{array}{c}\text { Slab } \\
\text { thickness } \\
\text { H (mm) }\end{array}$ & $\begin{array}{c}\text { Bubble } \\
\text { diameter } \\
\text { B (mm) }\end{array}$ & $B / H$ & $\begin{array}{l}\text { No. of } \\
\text { plastic } \\
\text { spheres }\end{array}$ & $\begin{array}{c}\boldsymbol{f}^{\prime} \boldsymbol{c} \\
(\boldsymbol{M P a})\end{array}$ & $\begin{array}{c}f_{y} \\
(\boldsymbol{M P a})\end{array}$ & $\underset{(\%)}{\rho}$ \\
\hline 1 & SD2 & \multirow{6}{*}{1000} & \multirow{6}{*}{1000} & \multirow{3}{*}{100} & -- & - & -- & 33.13 & \multirow{6}{*}{550} & \multirow{3}{*}{$\begin{array}{c}0.44 \\
3\end{array}$} \\
\hline 2 & BD2-bu 64 & & & & 64 & 0.64 & 144 & 34.66 & & \\
\hline 3 & BD2-bu 80 & & & & 80 & 0.80 & 100 & 33.34 & & \\
\hline 4 & SD3 & & & \multirow{3}{*}{125} & -- & -- & -- & 32.14 & & \multirow{3}{*}{$\begin{array}{c}0.28 \\
5\end{array}$} \\
\hline 5 & BD3-bu 64 & & & & 64 & 0.51 & 144 & 34.66 & & \\
\hline 6 & BD3-bu100 & & & & 100 & 0.80 & 64 & 33.34 & & \\
\hline
\end{tabular}

$1000 \mathrm{~mm}$

Table (2): Concrete Mixture Design.

\begin{tabular}{||c|c|c|c|c|c||}
\hline \multirow{2}{*}{ Designation } & \multirow{2}{*}{$\begin{array}{c}\text { Cement } \\
\left(\mathrm{kg} / \mathrm{m}^{3)}\right.\end{array}$} & \multicolumn{2}{|c|}{ Aggregate $\left(\mathrm{kg} / \mathrm{m}^{3}\right)$} & \multirow{2}{*}{$\begin{array}{c}\text { Water } \\
\left(\mathrm{kg} / \mathrm{m}^{3}\right)\end{array}$} & $\begin{array}{c}\text { w/c Ratio to Give } \\
\text { Slump } \\
140 \pm 10 \%\end{array}$ \\
\cline { 3 - 4 } & $\mathbf{4 2 5}$ & 735 & 1015 & $\mathbf{2 2 5}$ & $\mathbf{0 . 5 3}$ \\
\hline $\mathrm{C} 33$ & $\mathbf{4 2 5}$ & Coarse & \\
\hline
\end{tabular}

* Maximum size of aggregate was $10 \mathrm{~mm}$

Table (3): Test Result of Reinforcing Bars.

\begin{tabular}{||c|c|c|c|c||}
\hline $\begin{array}{c}\text { Nominal } \\
\text { Diameter }(\mathrm{mm})\end{array}$ & $\begin{array}{c}\text { Measured } \\
\text { Diameter }(\mathrm{mm})\end{array}$ & $\begin{array}{c}\text { Area } \\
\left(\mathrm{mm}^{2}\right)\end{array}$ & $\begin{array}{c}F_{y} \\
(\mathrm{MPa})\end{array}$ & $\begin{array}{c}F_{u} \\
(\mathrm{MPa})\end{array}$ \\
\hline 4 & 4 & 12.566 & 550 & 835 \\
\hline 5 & 4.994 & 19.588 & 550 & 817 \\
\hline
\end{tabular}

Table (4): Finite Element Representation of Structural Components.

\begin{tabular}{|c|c|}
\hline Structural Component & Element Designation in ANSYS \\
\hline Concrete & SOLID 65 \\
\hline Reinforcement & LINK-8 \\
\hline Steel Plate & SOLID 45 \\
\hline
\end{tabular}


Table (5): Material Properties Parameters for Slab Specimens.

\begin{tabular}{|c|c|c|c|c|c|c|c|c|}
\hline Material Type & Parameter & \multicolumn{5}{|c|}{ Definition } & & Value \\
\hline \multirow{9}{*}{ Concrete } & $f_{c}^{\prime}$ & \multicolumn{5}{|c|}{ Ultimate compressive strength (MPa) } & & 33.4 \\
\hline & $f_{t}$ & \multicolumn{5}{|c|}{ Ultimate tensile strength (MPa) } & & 3.1 \\
\hline & $B_{o}$ & \multirow{2}{*}{\multicolumn{5}{|c|}{ Shear transfer parameters }} & & 0.32 \\
\hline & $B_{c}$ & & & & & & & 0.52 \\
\hline & $E_{c}$ & & ung's moc & dulus o & elastic & ty $(\mathrm{MP}$ & & 27163 \\
\hline & $v$ & & & oisson's & ratio & & & 0.2 \\
\hline & \multicolumn{8}{|c|}{ Definition of stress-strain relationship for concrete } \\
\hline & Stress $(\mathrm{MPa})$ & $\mathbf{0}$ & 10.02 & 21.55 & 27.59 & 32.31 & 33.4 & 33.4 \\
\hline & Strain & $\mathbf{0}$ & 0.003689 & 0.0009 & 0.0013 & 0.0019 & 0.00245 & 0.003 \\
\hline \multirow{3}{*}{ Reinforcement } & $E_{s}$ & \multicolumn{5}{|c|}{ Modulus of elasticity(MPa) } & \multicolumn{2}{|c|}{200000} \\
\hline & $v$ & \multicolumn{5}{|c|}{ Poisson's ratio } & \multicolumn{2}{|r|}{0.3} \\
\hline & $f_{y}$ & \multicolumn{5}{|c|}{ Yield strength $(\mathrm{MPa})$} & \multicolumn{2}{|r|}{550} \\
\hline \multirow{2}{*}{ Steel Plates } & $E_{S}$ & \multicolumn{5}{|c|}{ Modulus of elasticity (MPa) } & \multicolumn{2}{|c|}{200000} \\
\hline & $v$ & \multicolumn{5}{|c|}{ Poisson's ratio } & \multicolumn{2}{|r|}{0.3} \\
\hline
\end{tabular}

Table (6): Comparison between experimental and numerical results.

\begin{tabular}{||c|c|c|c|c|c|c|c||}
\hline \multirow{2}{*}{ Slab name } & \multicolumn{4}{|c|}{ Experimental } & \multicolumn{2}{c|}{ Finite Element Analysis } & \multirow{2}{*}{ Pu $($ EXP $)$} \\
\cline { 2 - 8 } & $\begin{array}{c}P_{c r .} \\
(k N)\end{array}$ & $\begin{array}{c}P_{u} \\
(k N)\end{array}$ & $\begin{array}{c}\Delta_{u} \\
(m m)\end{array}$ & $\begin{array}{c}P_{c r .} \\
(k N)\end{array}$ & $P_{u}(k N)$ & $\begin{array}{c}\Delta_{u} \\
(m m)\end{array}$ & Pu(F.E.M) \\
\hline SD2 & 116 & 552 & 25.4 & 113 & 537 & 26.4 & 1.03 \\
\hline BD2-bu64 & 108 & 550 & 27.0 & 96 & 533 & 28.3 & 1.03 \\
\hline BD2-bu80 & 95 & 491 & 24.3 & 90 & 476 & 25.2 & 1.03 \\
\hline SD3 & 149 & 707 & 21.0 & 151 & 685 & 20.7 & 1.03 \\
\hline BD3-bu64 & 139 & 704 & 23.0 & 140 & 684 & 22.5 & 1.03 \\
\hline BD3-bu100 & 122 & 634 & 20.63 & 117 & 618 & 21.6 & 1.03 \\
\hline
\end{tabular}




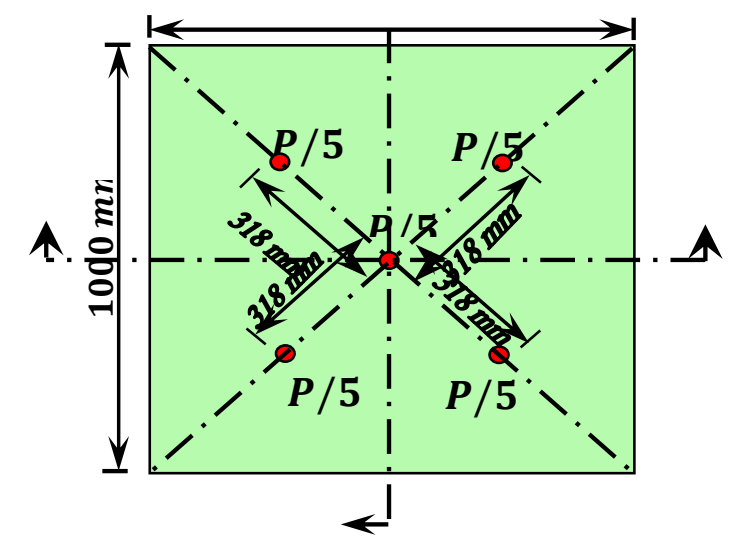

(a) Top View of Tested Slab

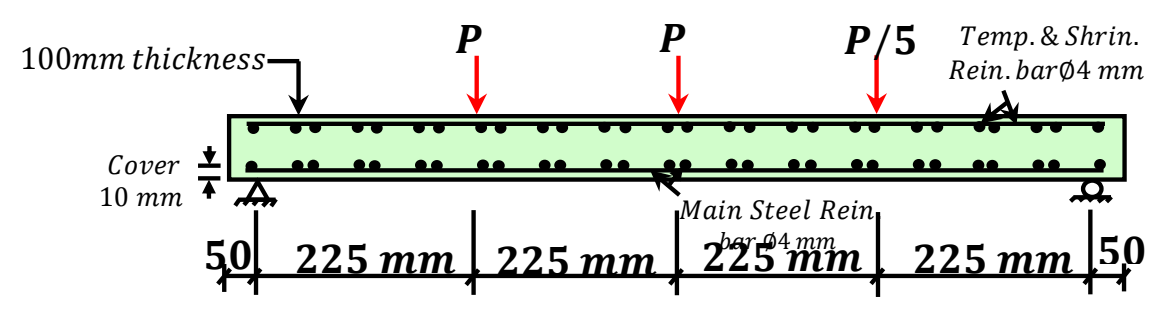

(b) Cross-Section in Solid Slab

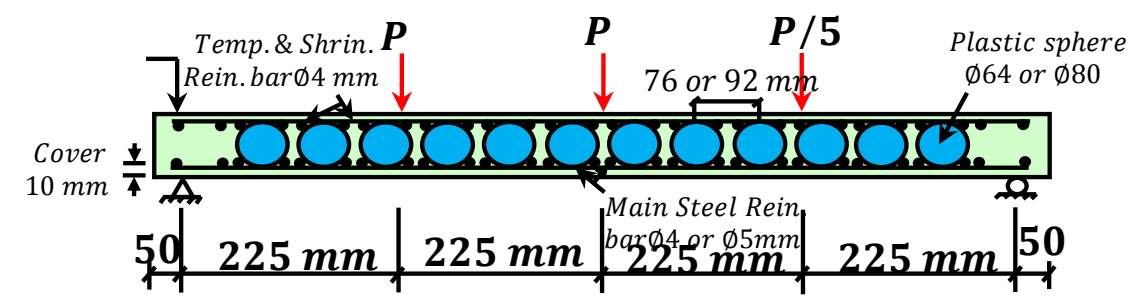

(c) Cross-Section in BubbleDeck Slab

Figure (1): Details and Dimensions of Test Slab Specimens.

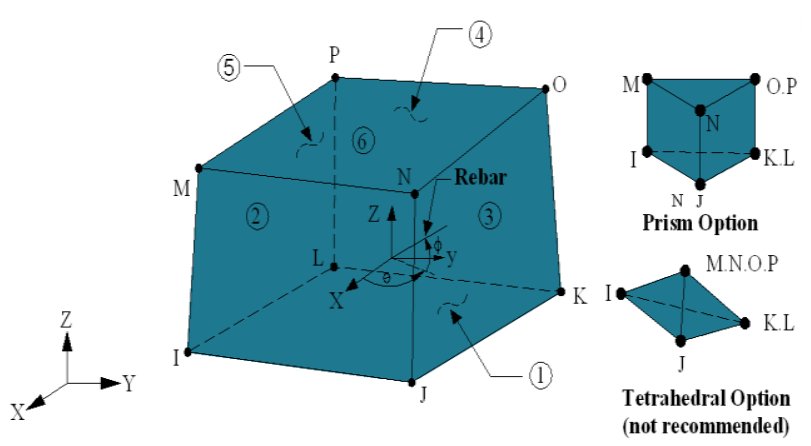

Figure (2): SOLID 65 Geometry ${ }^{(6)}$. 

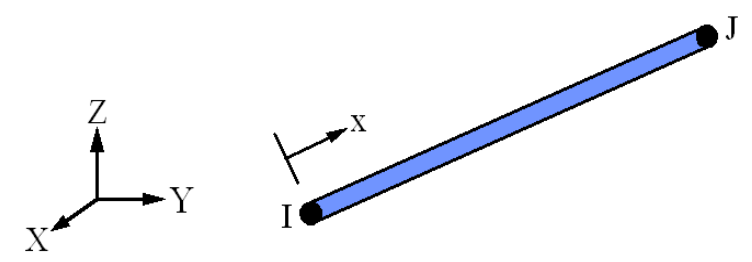

Figure (3): LINK8 Geometry ${ }^{(6)}$.

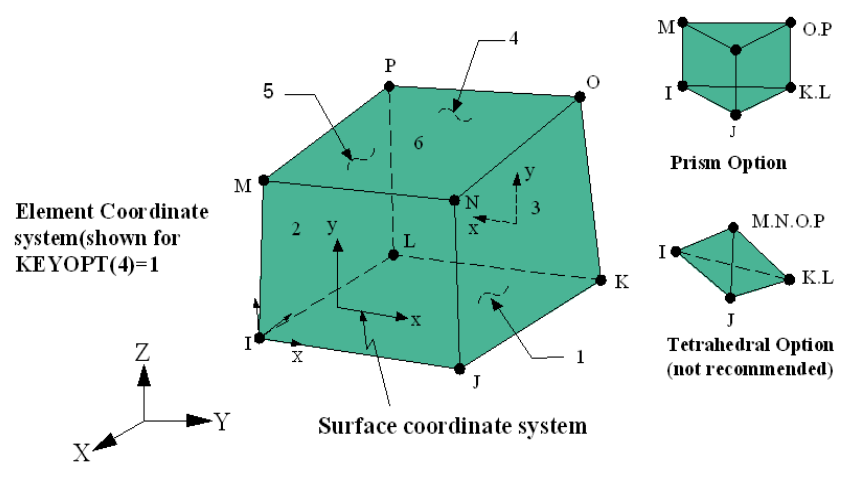

Figure (4): SOLID45 Geometry ${ }^{(6)}$.

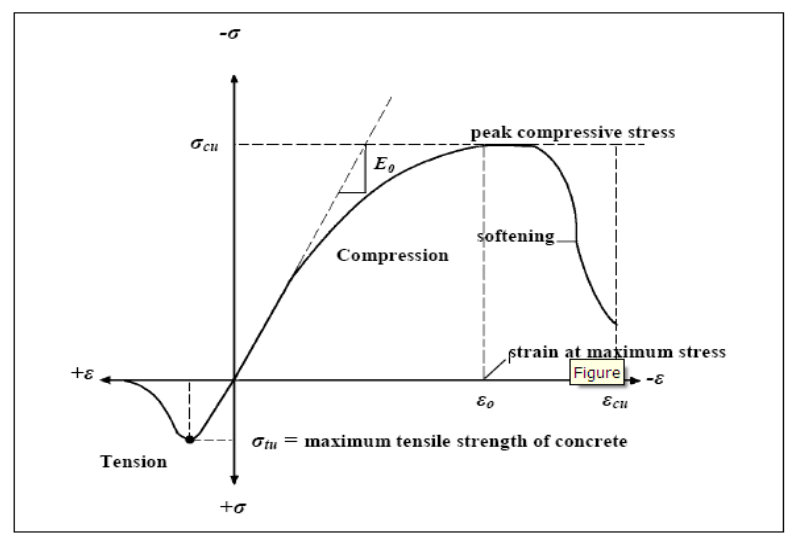

Figure (5): Typical Uniaxial Compressive and Tensile Stress-Strain Curve of Concrete ${ }^{(11)}$. 


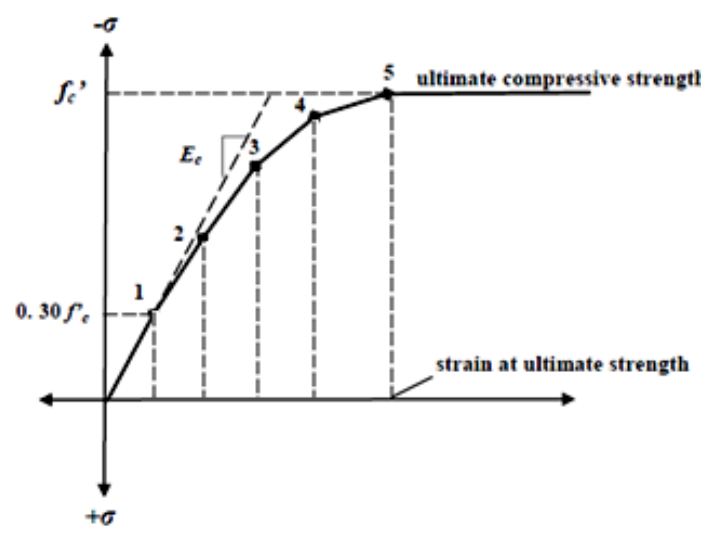

Figure (6): Simplified Compressive Uniaxial Stress-Strain Curve for Concrete ${ }^{(12)}$.

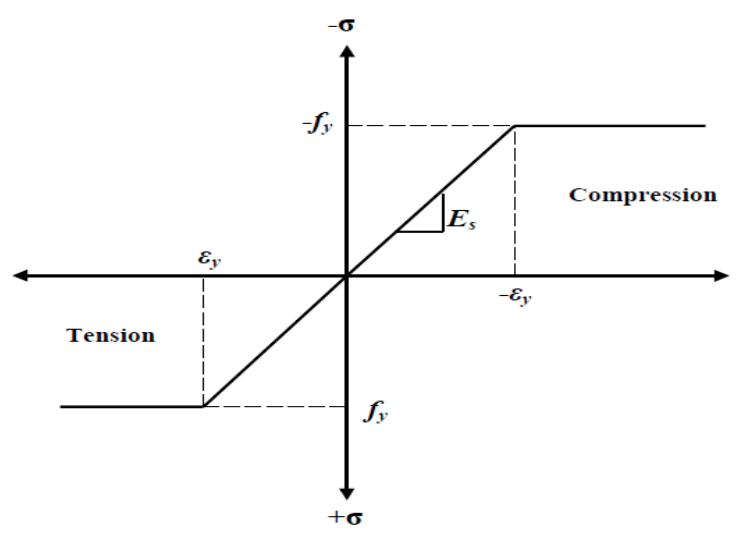

Figure (7): Stress-Strain Curve for Steel Reinforcement.

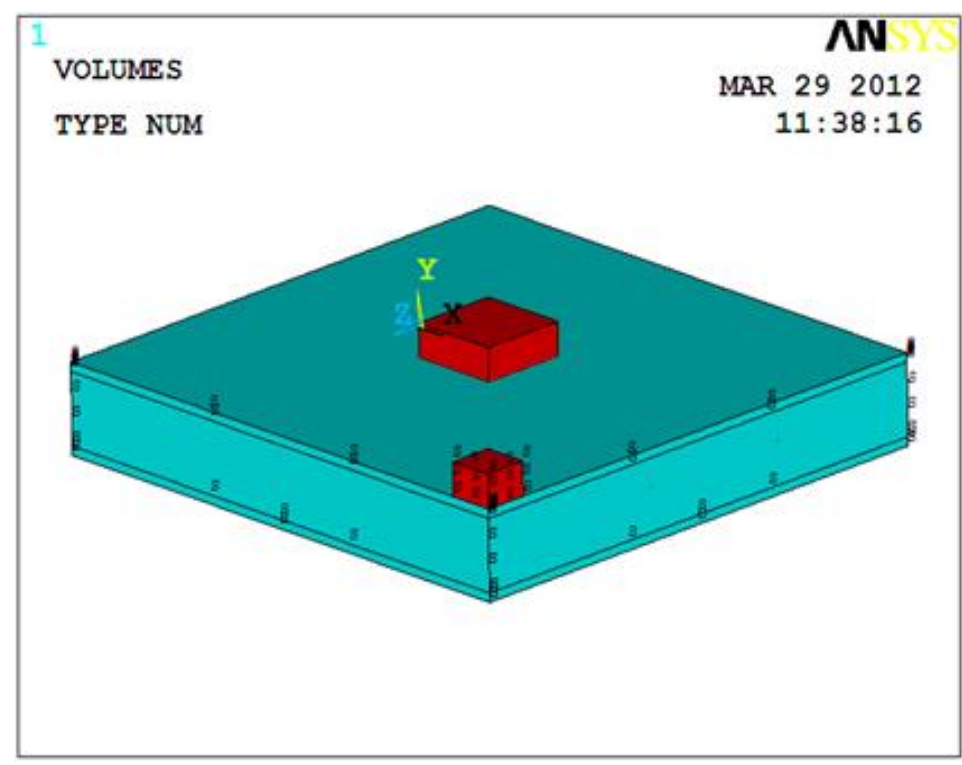

Figure (8): Modeling of BubbleDeck Slab as Volume. 


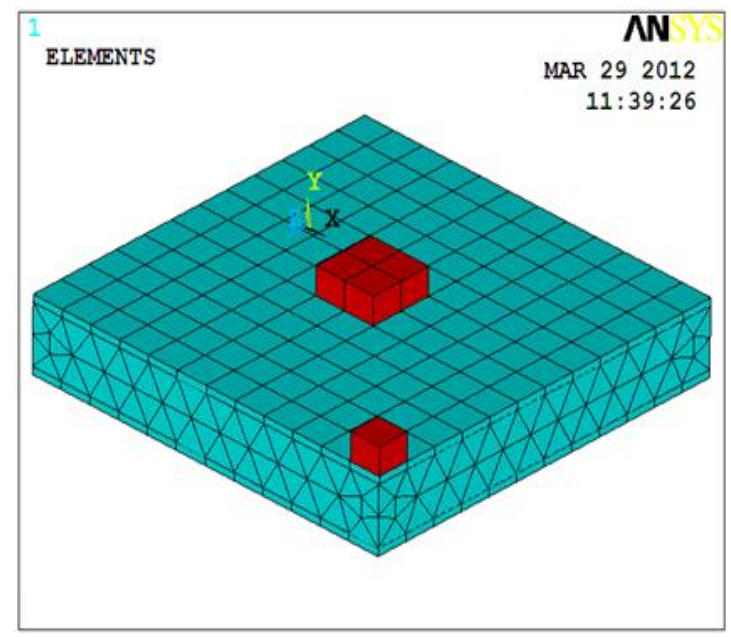

Figure (9): Meshing of BubbleDeck Slab.

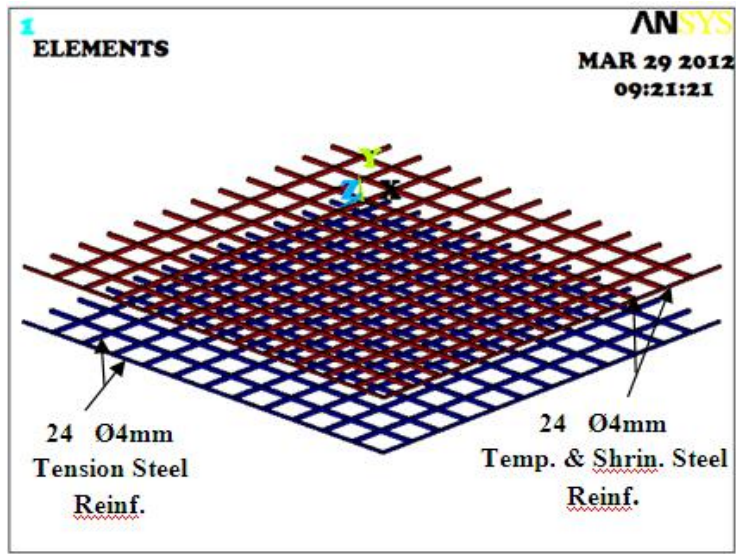

Figure (10): Reinforcement Modeling.

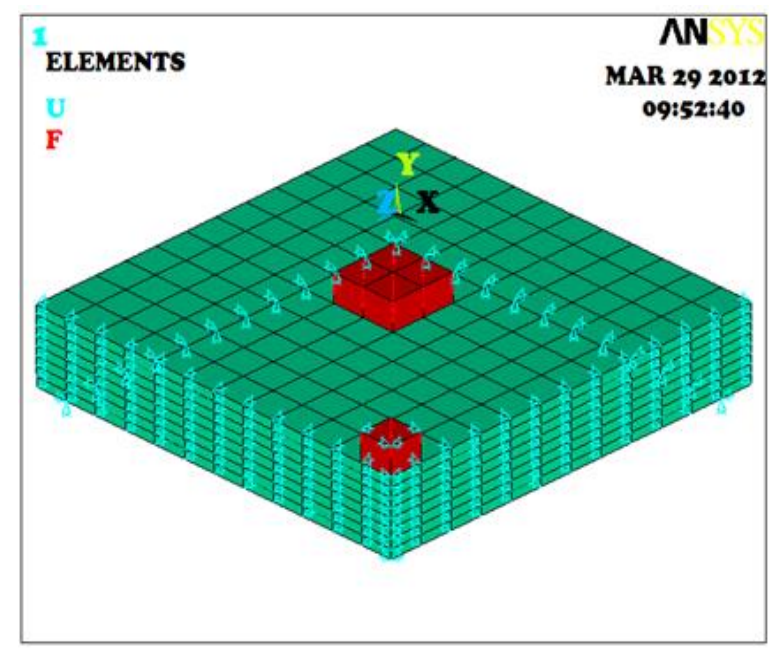

Figure (11): Symmetry of One Quarter. 


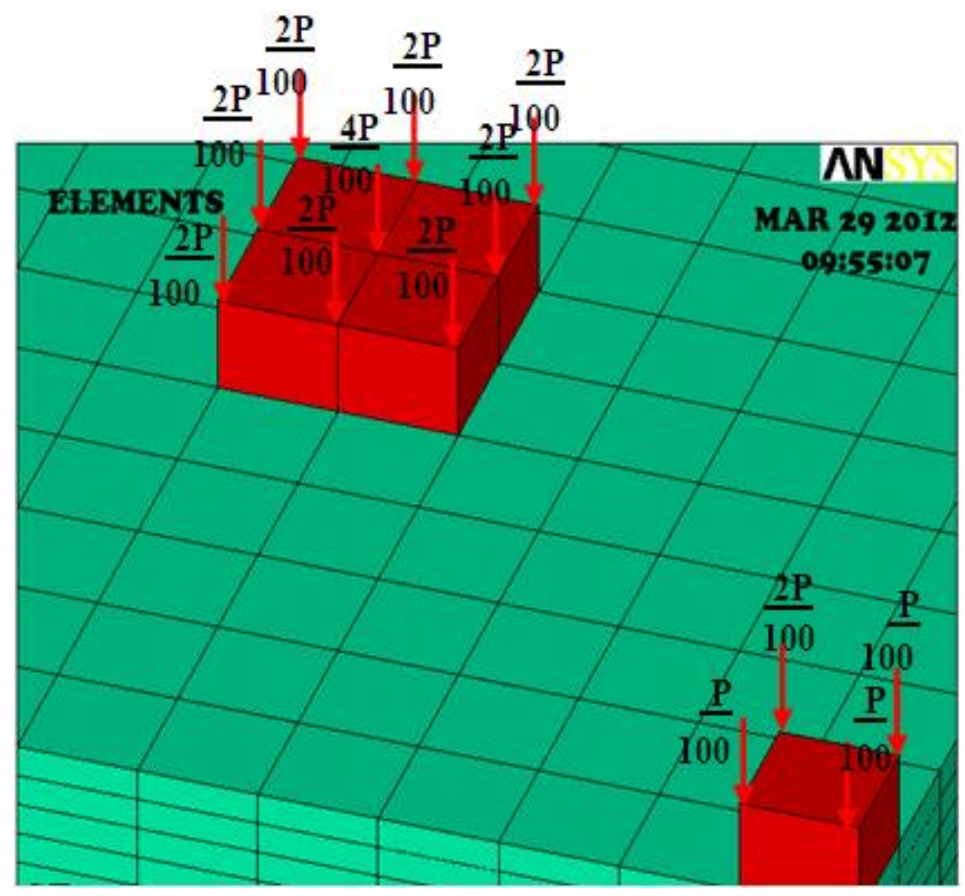

Figure (12): Boundary Condition for External Load.

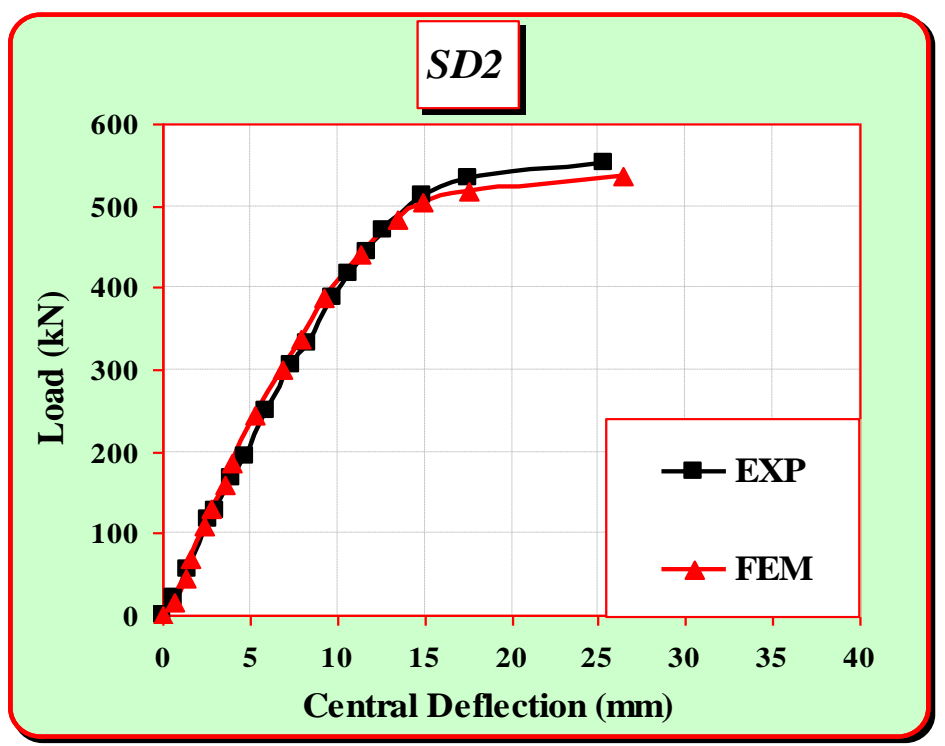

Figure (13): Load-Deflection Curve for (SD2). 


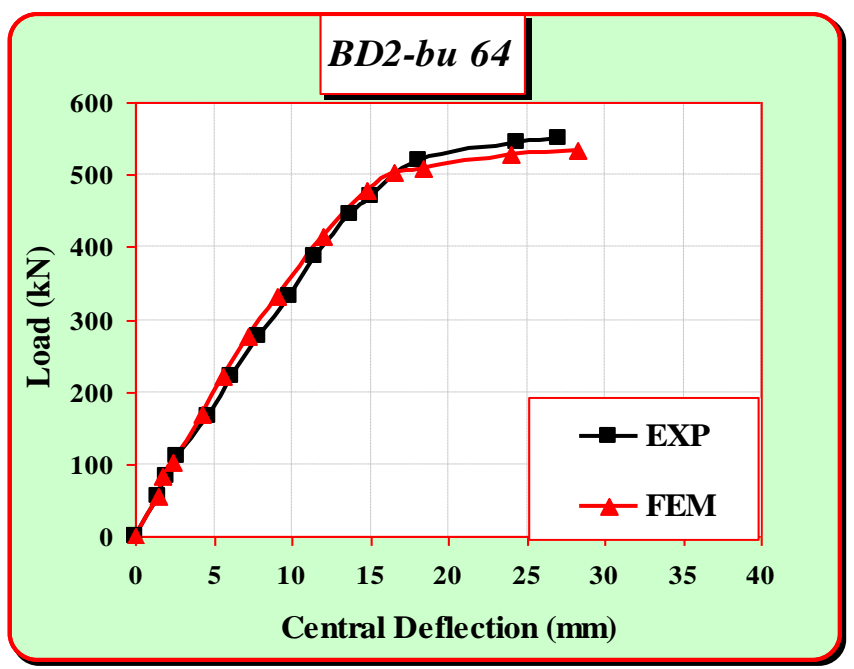

Figure (14): Load-Deflection Curve for (BD2-bu64).

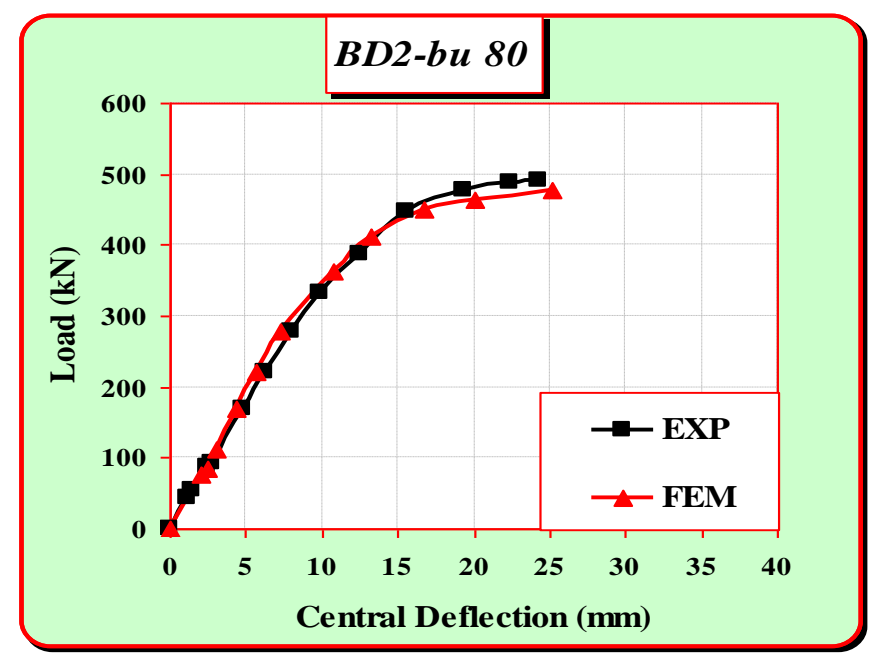

Figure (15): Load-Deflection Curve for (BD2-bu80).

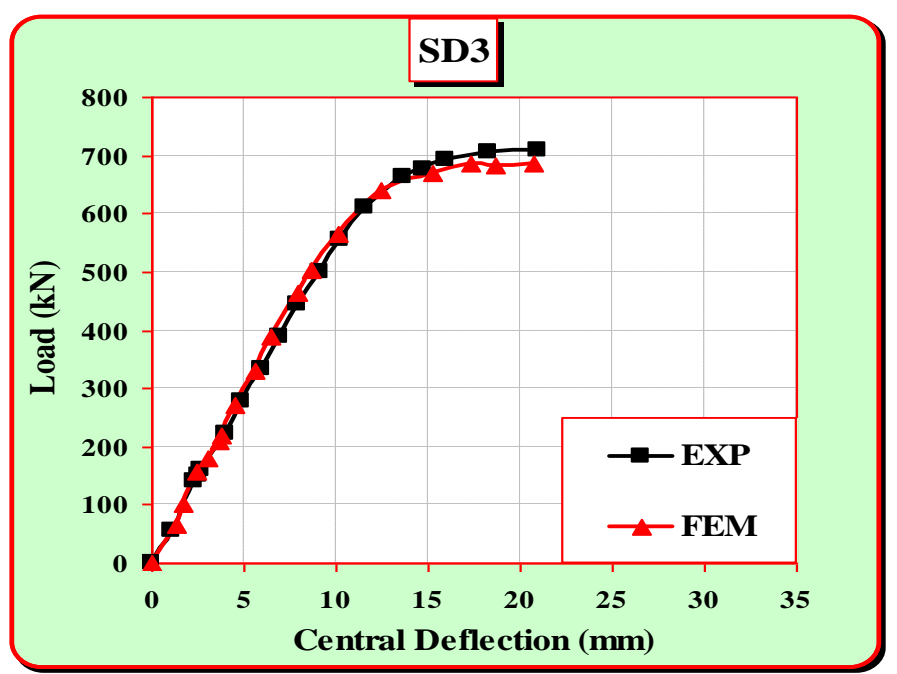

Figure (16): Load-Deflection Curve for (SD3). 


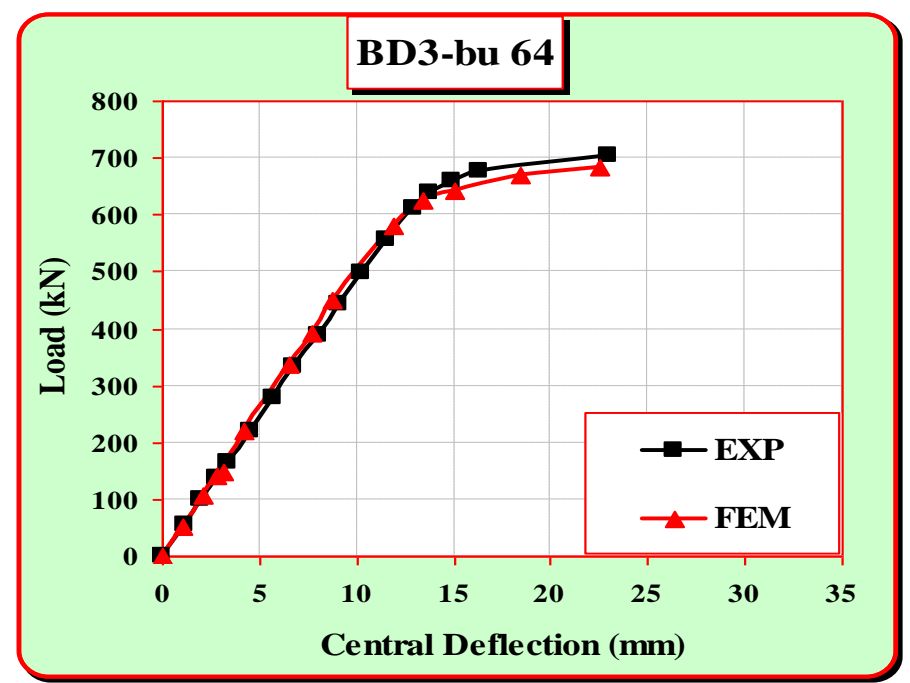

Figure (17): Load-Deflection Curve for (BD3-bu64).

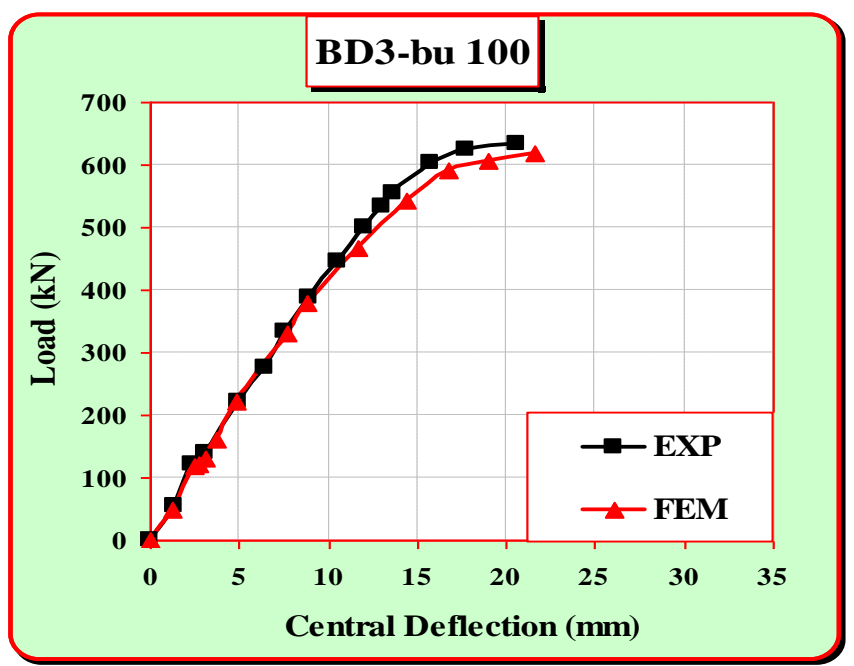

Figure (18): Load-Deflection Curve for (BD3-bu100).

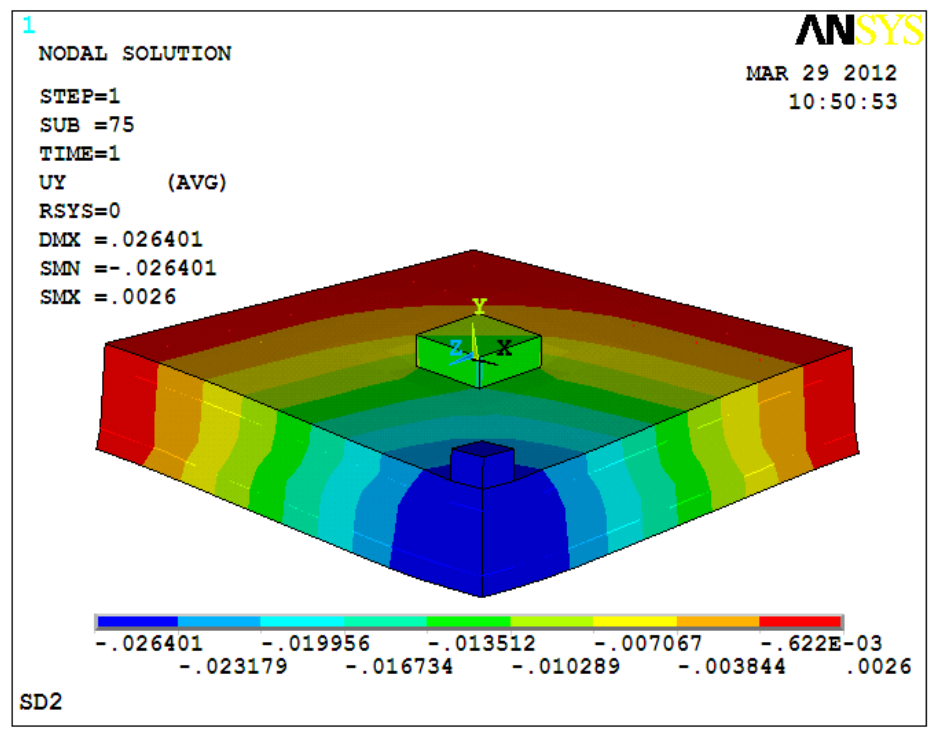

Figure (19): Deflected Shape for (SD2). 


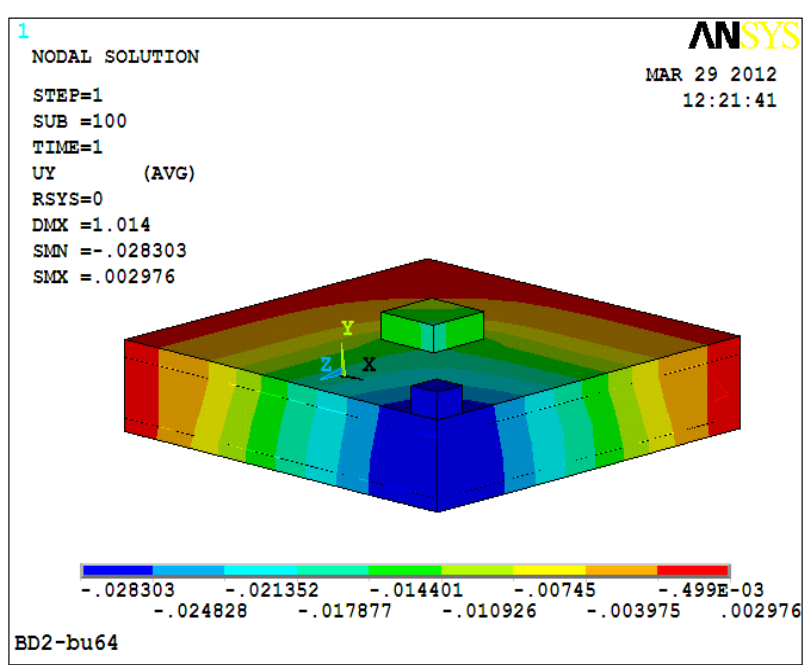

Figure (20): Deflected Shape for (BD2-bu64).

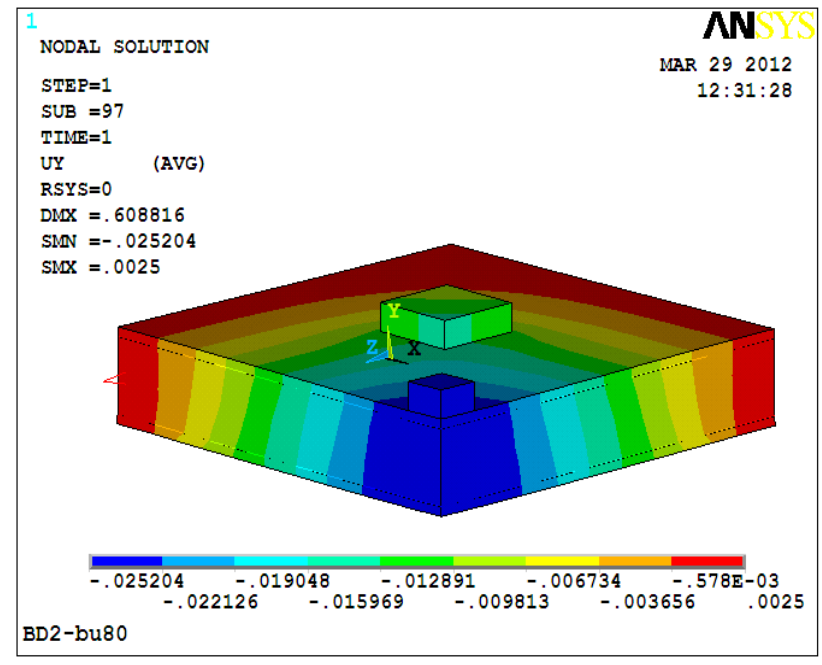

Figure (21): Deflected Shape for (BD2-bu80).

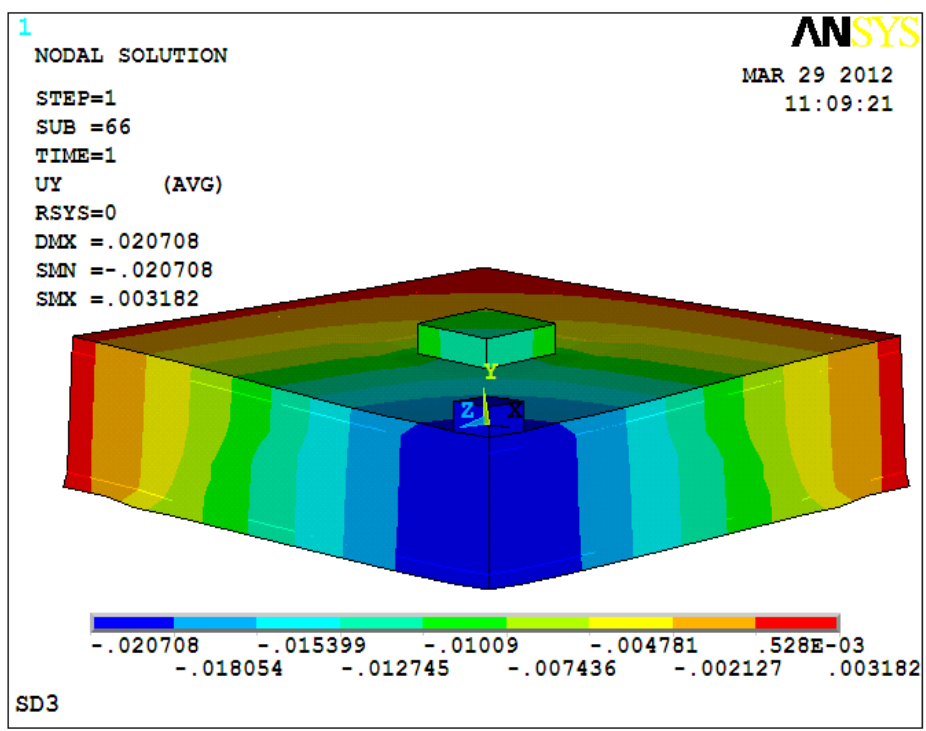

Figure (22): Deflected Shape for (SD3). 


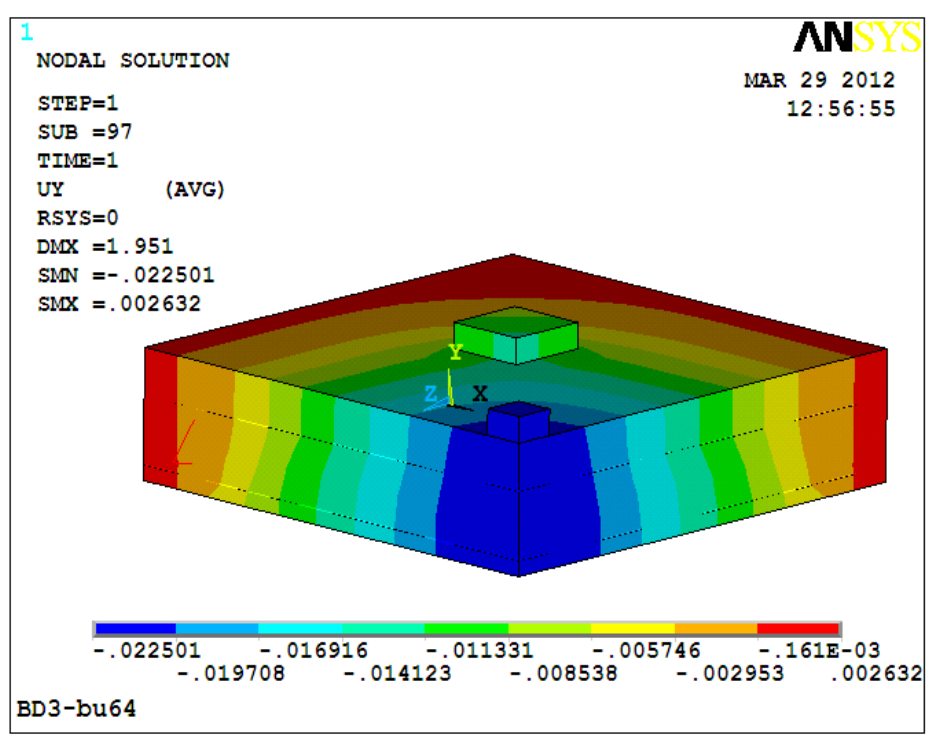

Figure (23): Deflected Shape for (BD3-bu64).

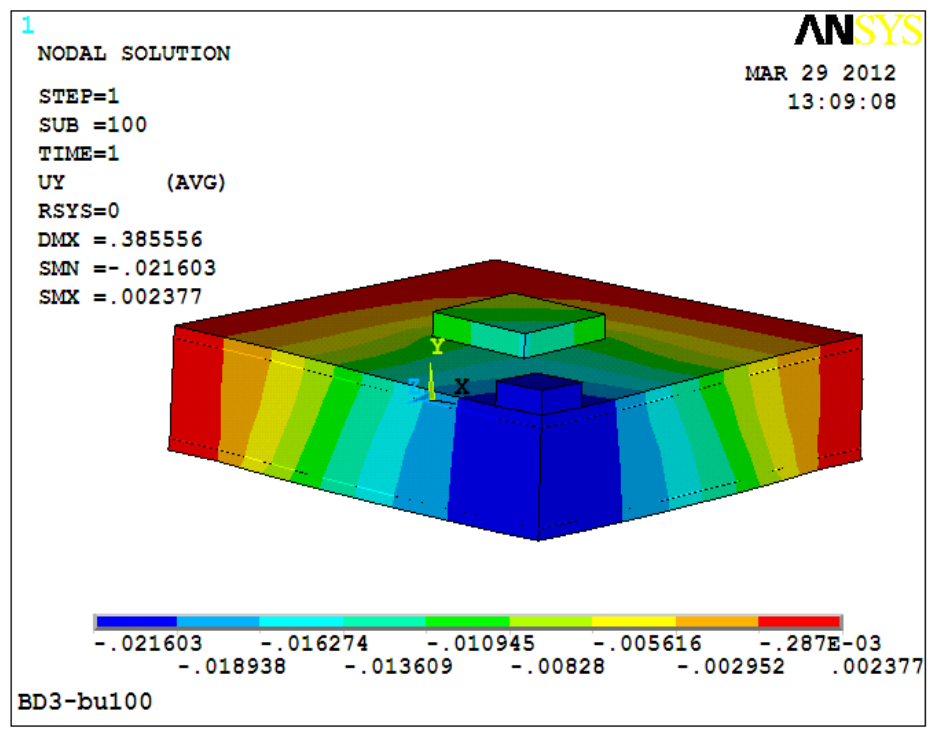

Figure (24): Deflected Shape for (BD3-bu100).

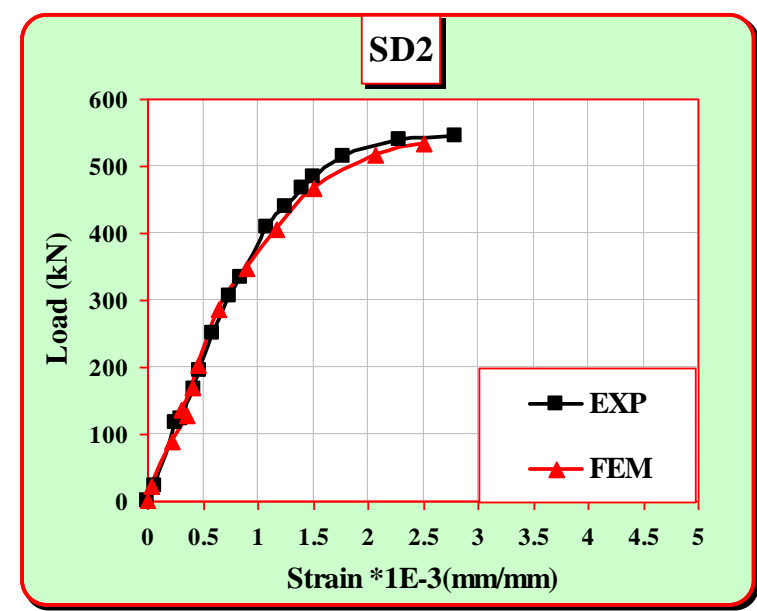

Figure (25): Load-Strain Curve for (SD2). 


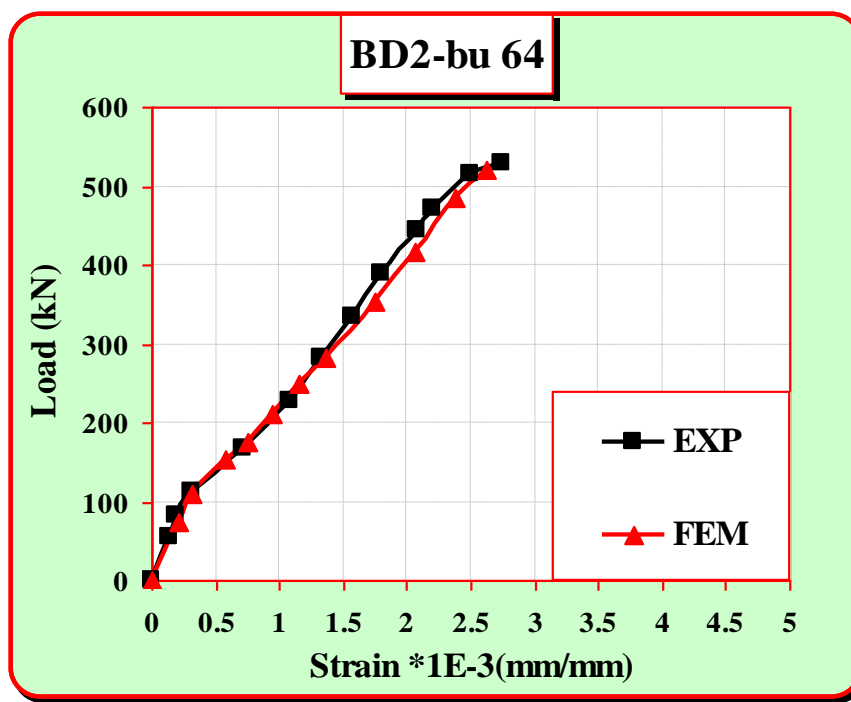

Figure (26): Load-Strain Curve for (BD2-bu64).

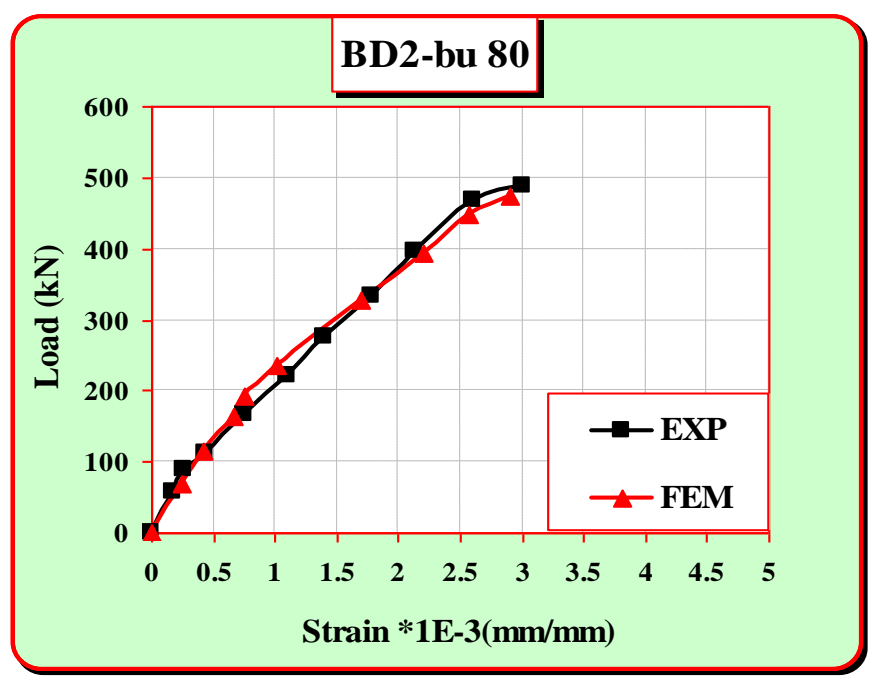

Figure (27): Load-Strain Curve for (BD2-bu80).

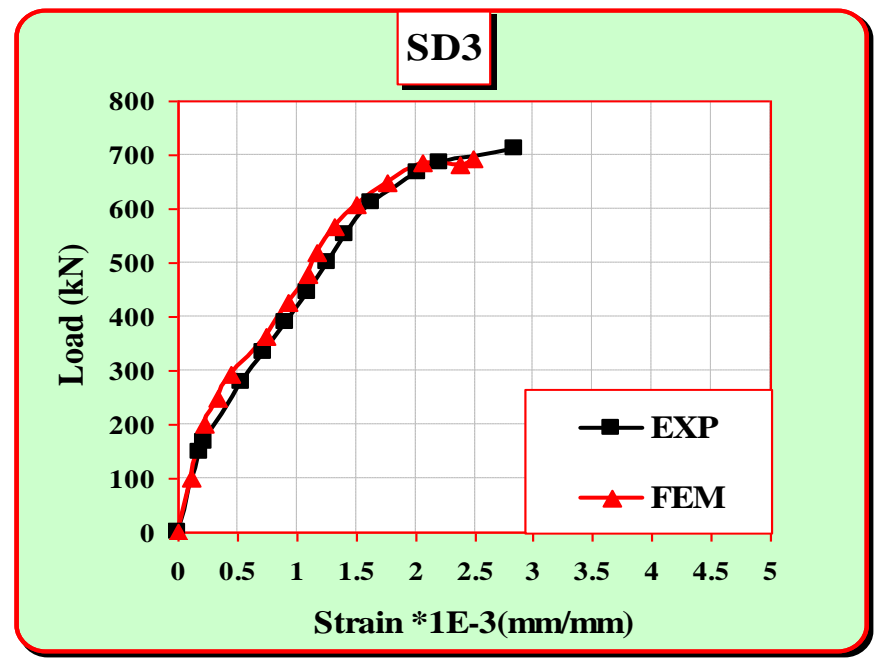

Figure (28): Load-Strain Curve for (SD3). 


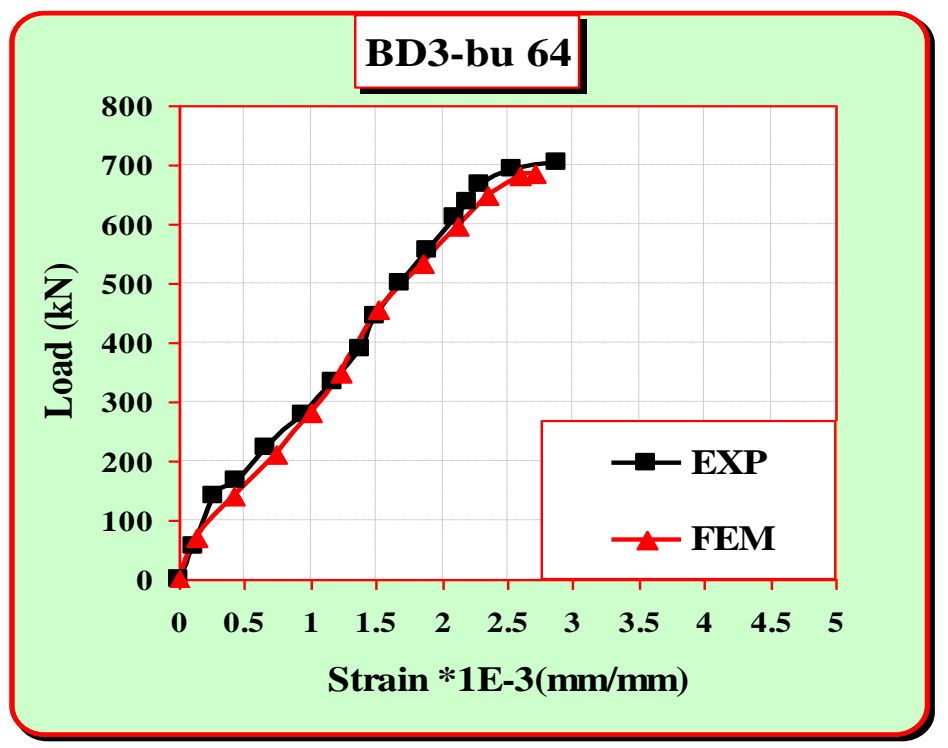

Figure (29): Load-Strain Curve for (BD3-bu64).

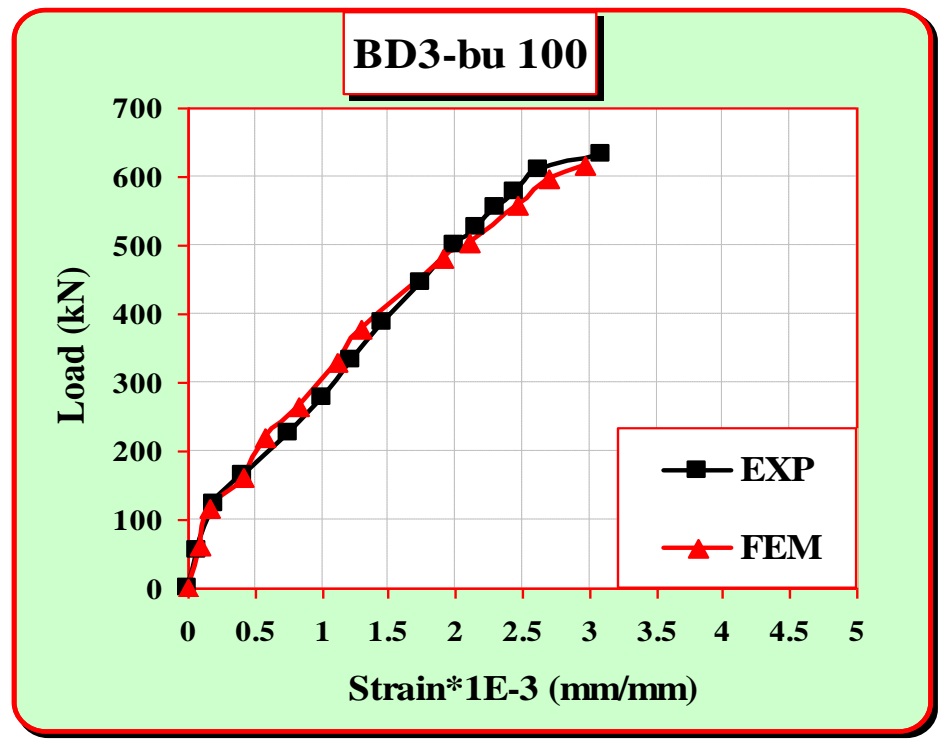

Figure (30): Load-Strain Curve for (BD3-bu100). 


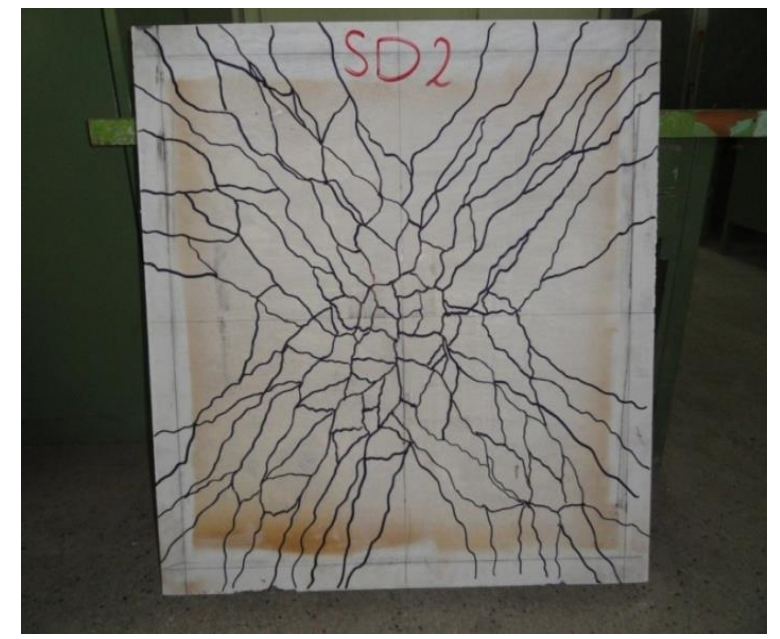

(a) Experimental.

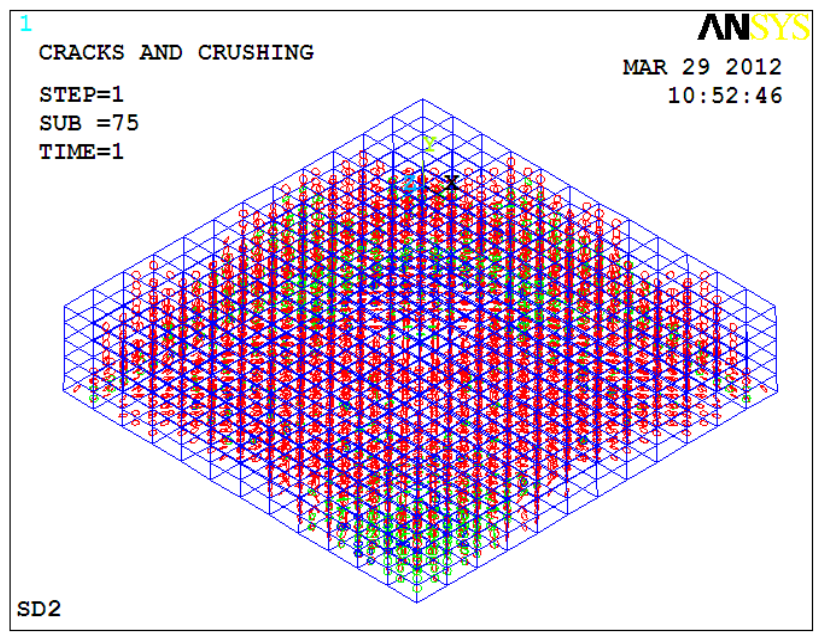

(b) Finite Element Analysis (One Quarter).

Figure (31): Crack Pattern at Ultimate Load for (SD2).

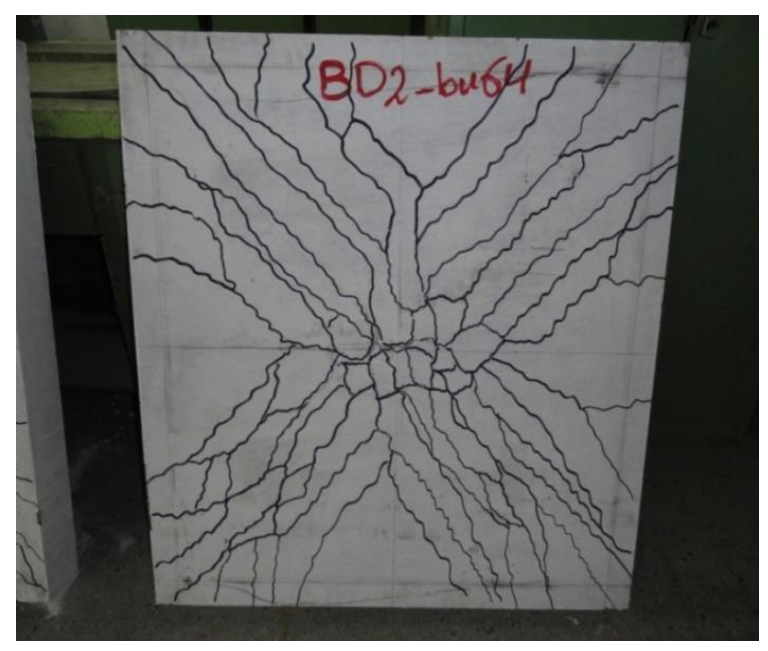

(a) Experimental.

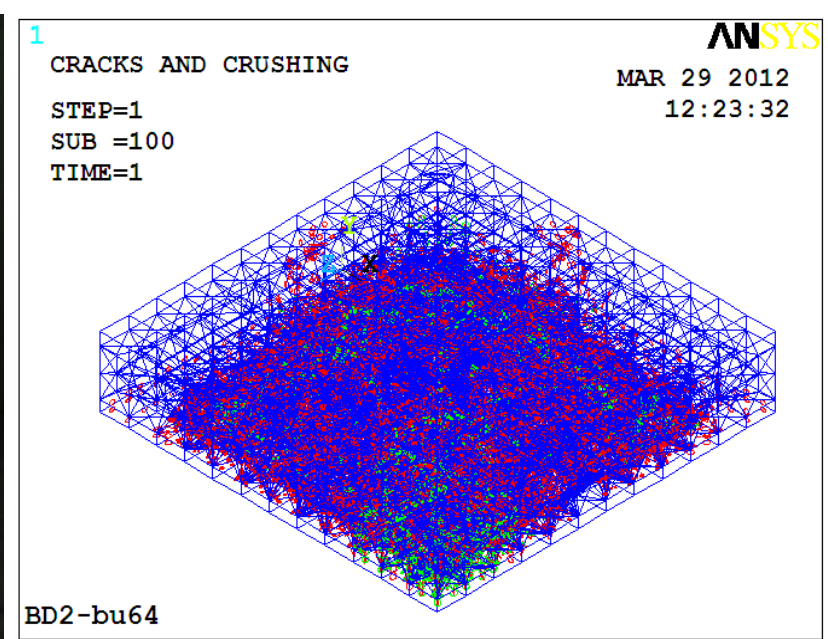

(b) Finite Element Analysis (One Quarter).

Figure (32): Crack Pattern at Ultimate Load for (BD2-bu64).

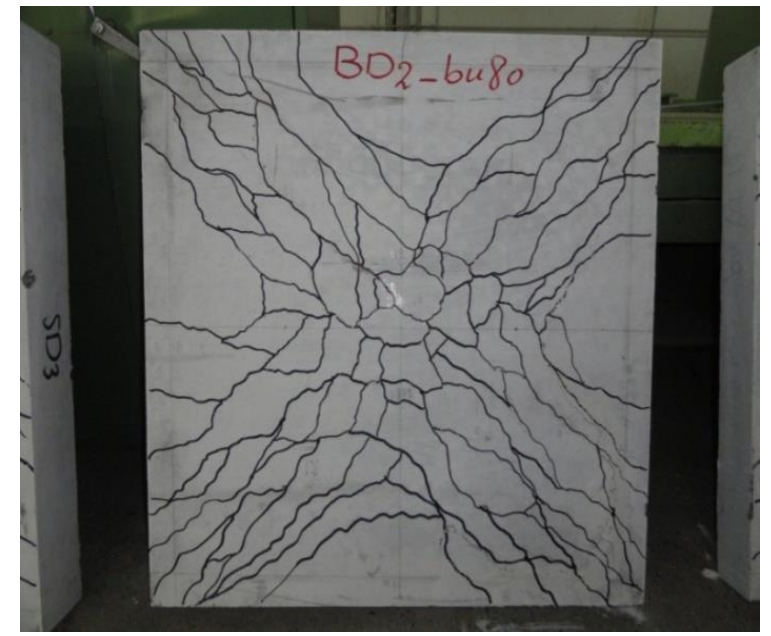

(a) Experimental.

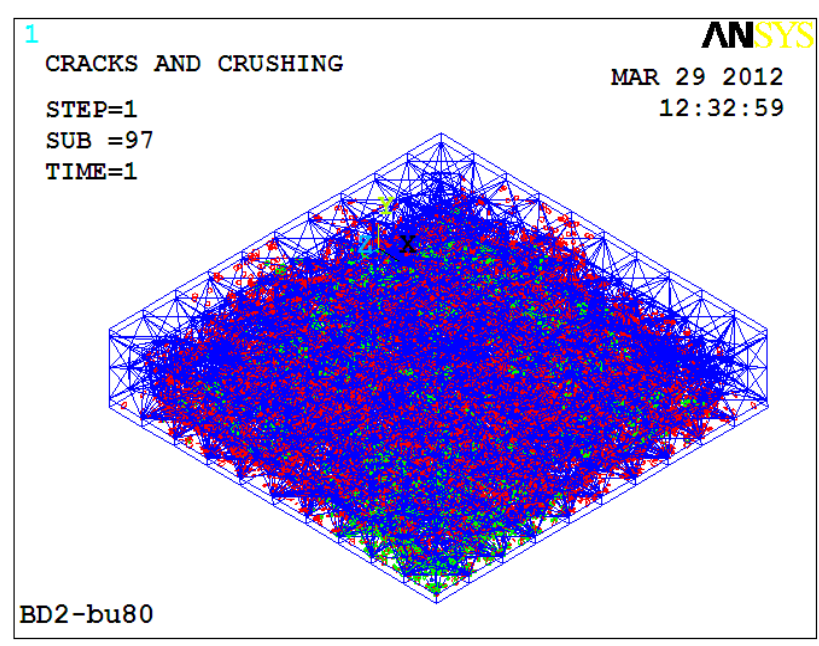

(b) Finite Element Analysis (One Quarter).

Figure (33): Crack Pattern at Ultimate Load for (BD2-bu80). 


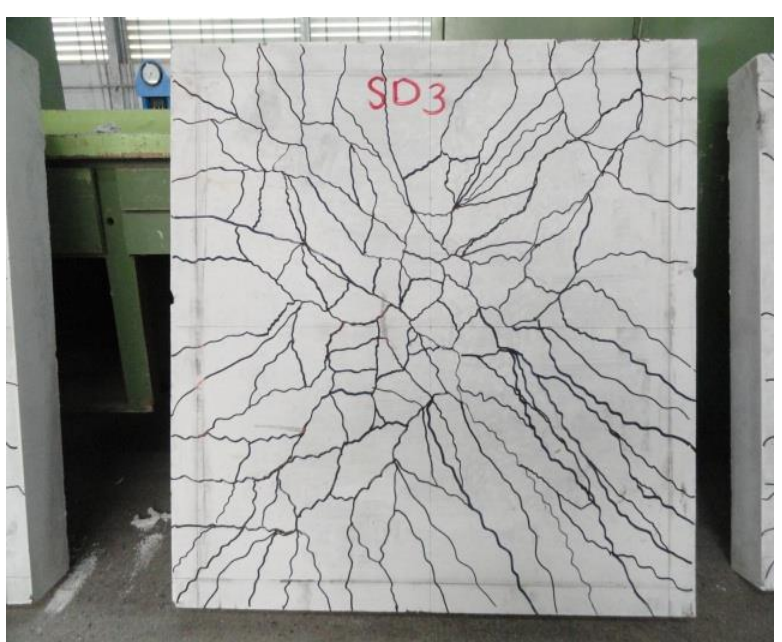

(a) Experimental

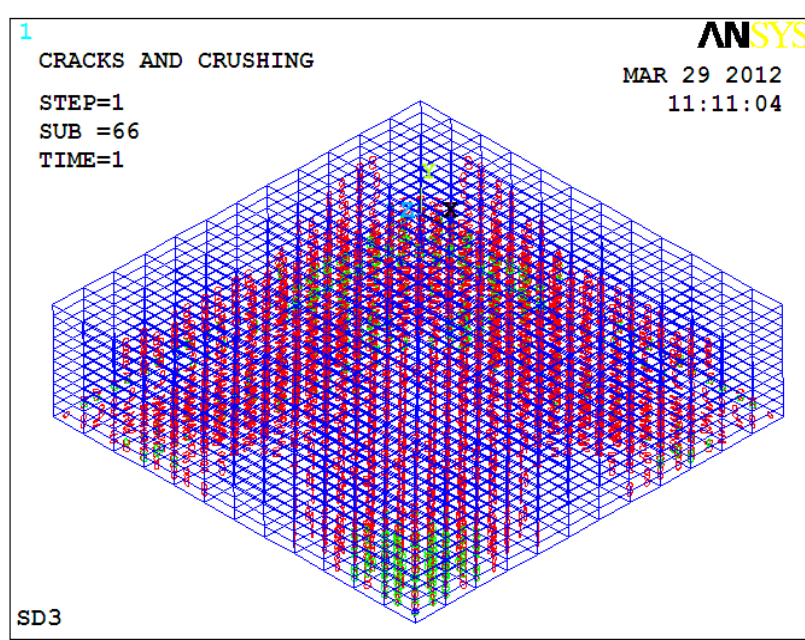

(b) Finite Element Analysis (One Quarter)

Figure (34): Crack Pattern at Ultimate Load for (SD3).

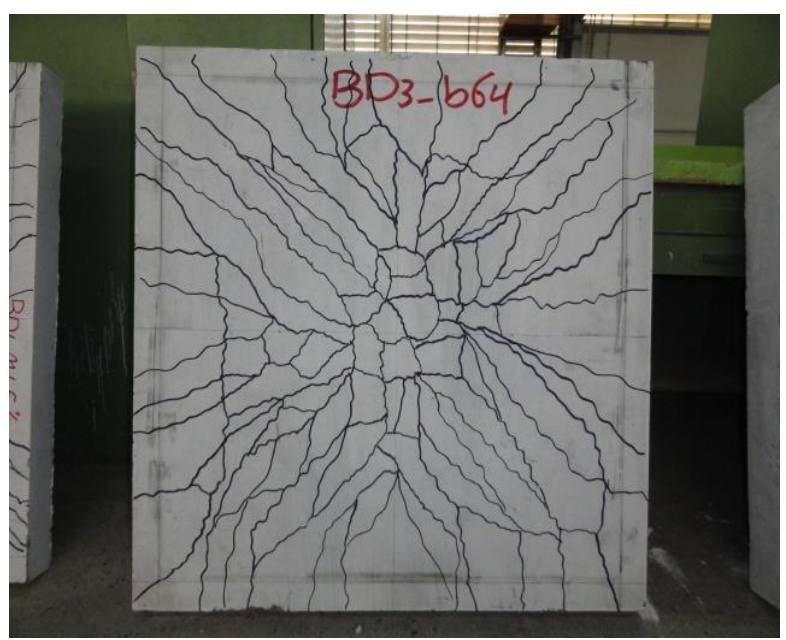

(a) Experimental

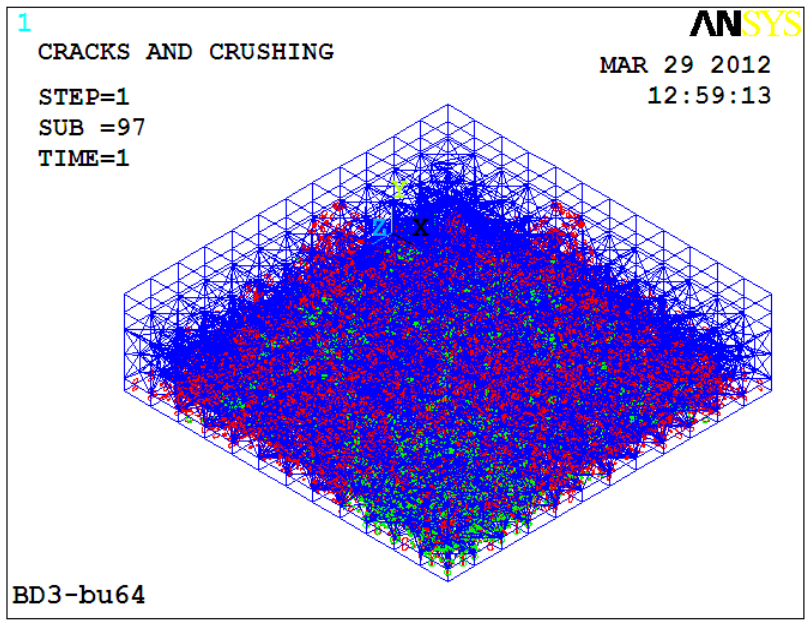

(b) Finite Element Analysis (One Quarter)

Figure (35): Crack Pattern at Ultimate Load for (BD3-bu64).

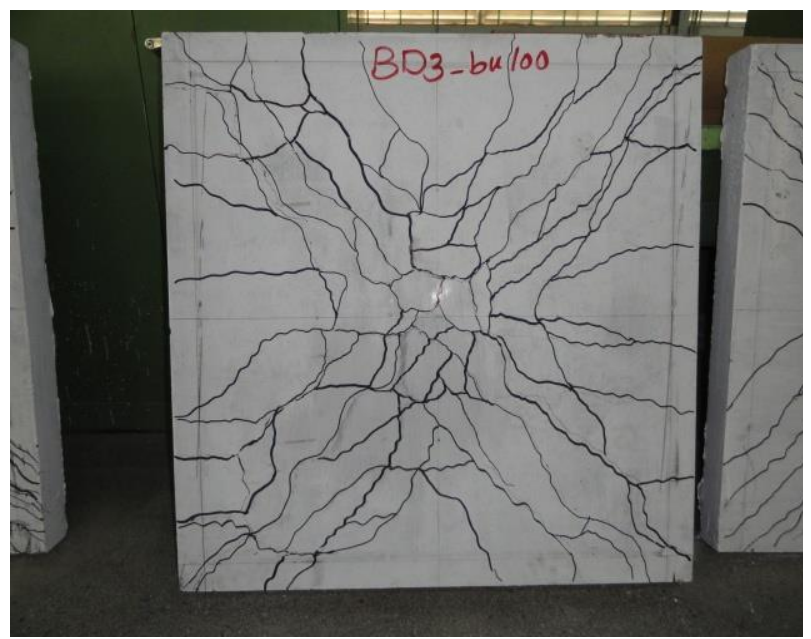

(a) Experimental

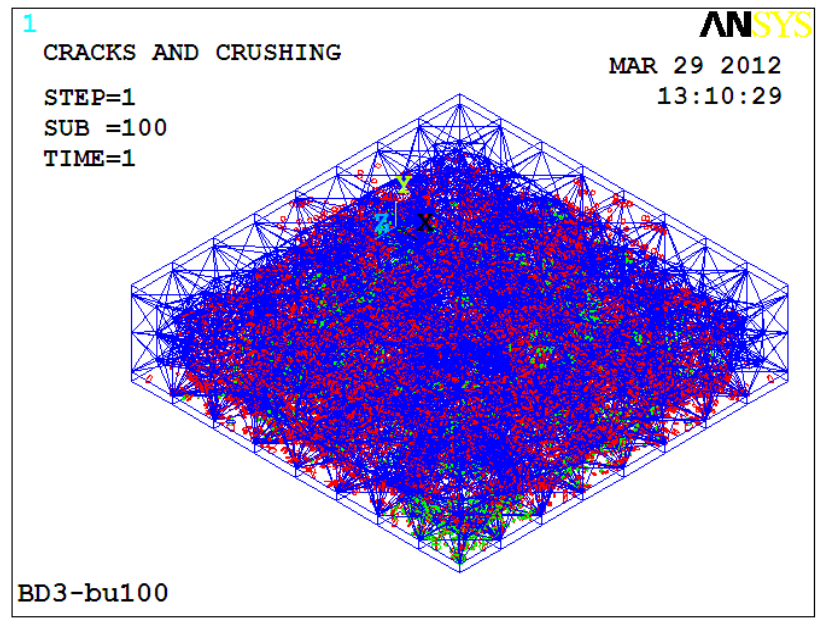

(b) Finite Element Analysis (One Quarter)

Figure (36): Crack Pattern at Ultimate Load for (BD3-bu100). 


\section{استخدام طريقة العناصر المحدة لتحليل البلاطات الخرسانية المسلحة الحاوية على فلى فجوات كروية}

عامر محمد إبراهيم 1'، نزار كامل علي ², وسام داود سلمان 3

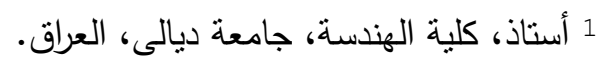

2 أستاذ مساعد، كلية الهندسة، جامعة بغداد، العراق.

3 طالب دكتوراه، كلية الهندسة، جامعة بغداد، العراق.

الخلاصة

لقد استخدم التحلبل العددي (طريقة العناصر المحددة باستخدام برنامج ANSYS) لمحاكاة أو لتمثيل

البلاطات الخرسانية المسلحة الحاوية على كرات مجوفة والمعرضة لخمس نقاط تحميل. تم تمثيل ست بلاطات بأبعاد 1م طول, 1م عرض و (1 0. و و 125 0م ) سمك وذات إسناد بسيط. سلوك المواد كان غير خطي بالنسبة لقضبان حديد التسليح والخرسانة,أما صفائح التحميل فكان سلوكها خطيا للوصول إلى نماذج ملائمة وقريبة للواقع, نتائج السلوك العام

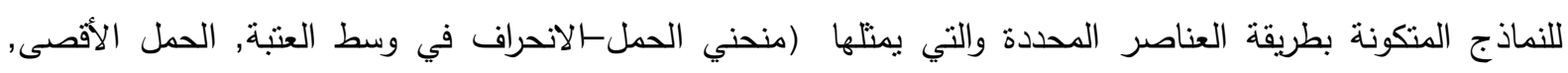
منحني الحمل-الانفعال الأقصى في الخرسانة وشكل التشققات) أظهرت تقارب كبير مع البيانات العملية للبحوث السابقة. النماذج المتكونة بطريقة العناصر المحددة في هذا البحث يمكن أن تستخدم لدراسة المحددات العملية للبلاطات الخرسانية المجوفة. 